\title{
LEPTOSPIROSIS SEROSURVEY IN BOVINES FROM BRAZILIAN PANTANAL USING IGG ELISA WITH RECOMBINANT PROTEIN LIPL32 AND MICROSCOPIC AGGLUTINATION TEST
}

\author{
Renata Graça Pinto Tomich ${ }^{1,2}$; Maria Rosa Quaresma Bomfim ${ }^{1}$; Matilde Cota Koury ${ }^{1}$; Aiesca Oliveira Pellegrin²; \\ Luiz Alberto Pellegrin ${ }^{2}$; Albert Icksang Ko ${ }^{3,4}$; Edel Figueiredo Barbosa-Stancioli ${ }^{1 *}$
}

${ }^{1}$ Departamento de Microbiologia, Instituto de Ciências Biológicas, Universidade Federal de Minas Gerais, Belo Horizonte, MG, Brasil; ${ }^{2}$ Empresa Brasileira de Pesquisa Agropecuária, Embrapa Pantanal, Corumbá, MS, Brasil; ${ }^{3}$ Centro de Pesquisas Gonçalo Moniz, Fundação Oswaldo Cruz, Salvador, BA, Brasil; ${ }^{4}$ Division of International Medicine and Infectious Diseases, Weill Medical College of Cornell University, New York, USA

Submitted: October 11, 2006; Returned to authors for corrections: May 15, 2007; Approved: November 15, 2007.

\begin{abstract}
This investigation was carried out in Brazilian Pantanal: region with important biodiversity. This region's climatic conditions, hydrology and geomorphology as well as the existence of great variety of wild species favor the maintenance of the Leptospira in the environment. The aim of this study was to evaluate IgG ELISA with recombinant protein LipL32 in comparison with microscopic agglutination test (MAT) and additionally contribute to the knowledge of the distribution of the one of most important worldwide zoonotic infection, assessing the seropositivity of bovine leptospirosis in beef cattle herds of Brazilian Pantanal, an important ecological preserved area, where cattle constitute not only the most important economic resource but also the major activity compatible of the conservation of natural resource of the region. Out of 282 samples of cattle serum analyzed, 143 (50.71\%) were positive in MAT. The serovar Hardjo (genotypic Hardjoprajitno and Hardjobovis), Wolffi and Ballum showed the largest frequency of reactive samples. In the IgG ELISArLipL32, 161 samples $(57.09 \%)$ were positive. This result was higher than obtained by MAT $(\mathrm{p}<0.001)$. The sensitivity of the ELISA test was $99.30 \%$ and the specificity was $86.33 \%$, based on the MAT. This test was shown to be a more sensitive, specific and accurate test for the diagnosis of bovine leptospirosis compared to the MAT.
\end{abstract}

Key words: Bovine Leptospirosis, IgG ELISA rLipL32, MAT

\section{INTRODUCTION}

Leptospirosis is a worldwide zoonotic infection, caused by pathogenic spirochetes of the genus Leptospira. In bovines the disease ranges from an acute clinical picture with fever, hematuria, hemoglobinuria, meningitis and death, to a chronic disease that cause reproductive problems, as for instance, abortion, mummified fetuses, birth of weak calves, increased interval between parturitions, irregular estrus, retention of fetal membranes and infertility (12). The infection sources are infected animals which contaminate the pasture, water and other food sources with urine, aborted fetuses and infected uterine discharge. The leptospires persistence in a given region is related to high humidity and temperature, neutral and slightly alkaline soils, presence of organic matter, existence of wildlife animals and the presence of infected animals in the herd. Amongst the wildlife animal reservoirs are rats, foxes, jackals, raccoons, skunks, weasels, wild cats, crab-eating raccoons and others $(2,12,29)$.

In Brazil, high prevalence rates of leptospirosis in bovines have been reported. In Pantanal, climate conditions (yearly average temperature of $32^{\circ} \mathrm{C}$ ), hydrology and geomorphology (plains composed by various rivers and temporary streams with low declivity, which makes it a poor drainage system with periodic flooding) (34), as well as the great diversity of wildlife animals were favorable factors for the maintenance of the

*Corresponding Author. Mailing address: Departamento de Microbiologia, Instituto de Ciências Biológicas da Universidade Federal de Minas Gerais, Cx.P 486, Belo Horizonte, MG, Brasil, CEP: 31.270-901. Tel.: +55 313499 2753; Fax: +55 313499 2730. E-mail: edelfb@icb.ufmg.br 
bacteria in the environment. In this region, free-range cattle's breeding is the most important economic activity. This cattle production system has been used for more than two hundred years and has been compatible of the conservation of natural resource of this region.

The reproductive efficiency of the bovines in Pantanal is low (1) and abortion, repeated estrus, mummified fetuses, birth of weak calves, retention of fetal membranes and infertility were frequently relate problems (28). Leptospirosis emerges as a possible cause of these low rates. However, studies of the prevalence of Leptospira sp. in herds of this region are still incipient. Once the major product of bovine livestock of this region is the calf, a reproductive problem has an important economic impact.

The ELISA and MAT are the most commonly used laboratory methods and MAT is considered the gold standard test for diagnosis of Leptospirosis. The use of IgG ELISA with recombinant protein LipL32 (IgG ELISA rLipL32) for the leptospirosis serodiagnosis in human (16), canine (10) and bovine (7) was reported recently.

The objective of this study was to evaluate $\operatorname{IgG}$ ELISA rLipL32 in comparison with MAT and additionally contribute to the knowledge of the distribution of the one of most important worldwide zoonotic infection by investigate the leptospirosis seropositivity in beef cattle herds of the Brazilian Pantanal, an important ecological preserved area, where the bovine leptospirosis serodiagnosis are still incipient.

\section{MATERIALS AND METHODS}

\section{Area of Study and sample collection}

The Pantanal is a sedimentary plain located in the center of South America, between the parallels $16^{\circ}$ and $21^{\circ} \mathrm{S}$ and the meridians $55^{\circ}$ and $58^{\circ} \mathrm{W}$, approximately $80 \%$ inside Brazilian territory, $15 \%$ in Bolivian territory and 5\% in Paraguay. The Brazilian Pantanal is located in the country's central-east region, between the parallels $17^{\circ}$ and $21^{\circ} \mathrm{S}$ and the meridians $56^{\circ}$ and $59^{\circ} \mathrm{W}$ with $64.6 \%$ of its area in Mato Grosso do Sul State and $35.4 \%$ in Mato Grosso State. This marshy plain is located in the Paraguay River basin, which is constituted by various rivers and temporary streams with low declivity and it forms a slow drainage system that leads to periodic flooding with variable duration and extension. Due to the region's hydrology and geomorphology heterogeneity, the Pantanal is divided in 11 sub-regions. In this study, 282 bovines from five beef cattlebreeding farms were sampled, these were derived from the following sub-regions: Aquidauna (Farm 1, $\mathrm{n}=40$ ), Nhecolândia (farm 2, n= 46, farm 3, n= 43 e farm 4, n= 78) and Paraguay (farm

5, $\mathrm{n}=75$ ) (Fig. 1). Bovine blood samples were collected by puncturing the jugular or caudal vein with a sterile needle under aseptic condition. The animals received humane care as outlined in the "guide for care and use of laboratory animals" (25). After blood coagulation at room temperature, sera were collected and stored at $-20^{\circ} \mathrm{C}$.

The properties sampled had an average total area of 15,766 ha, mean number of cattle of 5,228, used the free-range farming technique, adopted low technology and had few grazing subdivisions, high predominance of native pasture, nonvaccinated herds for leptospirosis and zebu cattle. In all farms there are sandy and acid soils, but clay alkaline soils are also present, with the exception of farm 5, Paraguay sub-region, which according to the owner have clay soils. The wildlife animals commonly seen in the farms are: sylvan rats, capybaras, whitelipped peccaries, feral pigs, coatis, deer, skunks, crab-eating foxes, and crab-eating raccoons.

\section{Microscopic agglutination test}

Antibodies to leptospira were detected by MAT according to Faine (13). Live cultures of 13 reference strains of leptospira serovars, representing nine serogroups of $L$. interrogans (sensu lato qualification) were used (Table 1). Reference samples were 
Table 1. Reference strains of Leptospira serovars (sensu lato) used in microscopic agglutination test (MAT).

\begin{tabular}{lcc}
\hline \multicolumn{1}{c}{ Serogroup } & Serovar & Strain \\
\hline Australis & Australis & Ballico \\
& Bratislava & Jez bratislava \\
Icterohaemorrhagiae & Copenhageni & M20 \\
Hebdomadis & Hebdomadis & Hebdomadis \\
Pomona & Pomona & Pomona \\
Sejroe & Hardjo & Hardjoprajitino \\
& Wolffi & 3705 \\
& Hardjobovis & Lely 607 \\
Shermani & Sejroe & M84 \\
Grippotyphosa & Shermani & $1342 \mathrm{~K}$ \\
Ballum & Grippotyphosa & Moskva V \\
Tarassovi & Ballum & Mus 127 \\
& Tarassovi & Perepelitsin \\
\hline
\end{tabular}

obtained from the reference laboratory of the Royal Tropical Institute of Amsterdam, Holland. Reciprocal agglutination titres greater than or equal to 100 were considered positive reactions. Since the studded herds are not vaccined, bovine serum sample was titred up to 1600 .

\section{Enzyme-linked immunosorbent assay (ELISA)}

ELISA using the recombinant protein LipL32 (rLipL32) was carried out according to Bomfim et al. (7). Briefly, polystyrene microtitre plates (Corning) were coated with rLipL32 (5 ng/ well - suspended in $50 \mu \mathrm{L}$ of $0.05 \mathrm{M}$ sodium carbonate buffer $\mathrm{pH}$ 9.6). Plates were incubated under constant agitation (room temperature - RT, 2 hours). After washing twice with distillated water, plates were subsequently washed three times in wash solution (PBS pH 7.4 with $0.05 \% \mathrm{v} / \mathrm{v}$ tween 20 - PBST). The blocking was done with $1 \% \mathrm{w} / \mathrm{v}$ bovine albumin (Sigma) in PBST (blocking solution) for 4 hours at RT. After three washes with PBST, $100 \mu \mathrm{L}$ of sera diluted 40 -fold in blocking solution was added to each well. Sera were tested in duplicate. The plates were incubated for 1 hour at RT with agitation. After washing in PBST, each well received $100 \mu \mathrm{L}$ of a 40,000-fold dilution of conjugated antibody (anti-bovine $\gamma$-chain rabbit antibodies conjugated to horseradish peroxidase - SIGMA in PBST). Plates were incubated for 1 hour at RT with agitation. Subsequently, plates were washed three times with PBST and twice with PBS and incubated (20 minutes in the dark at RT) with $50 \mu \mathrm{L}$ of ortophenylenediamine (20 mg - SIGMA) dissolved in $50 \mathrm{~mL}$ of $0.03 \%(\mathrm{v} / \mathrm{v})$ hydrogen peroxide, $25 \mathrm{mM}$ citric acid and $50 \mathrm{mM} \mathrm{Na}_{2} \mathrm{HPO}_{4}$ (pH 5.0). The colorimetric reaction was stopped by adding $25 \mu \mathrm{L}$ of $\mathrm{H}_{2} \mathrm{SO}_{4} 2 \mathrm{M}$ and optical density was measured at $492 \mathrm{~nm}$ (TITERTEK MULTISKAN reader MCC; 340-MKII).

\section{ELISA Cut-off point determination}

The frequency distributions of the optical density (OD) values obtained for the positive and negative sera were determined. Diagnostic accuracy of tests and the cut-off threshold were analyzed according to receiver operator characteristic (ROC) curve analysis, using Win Episcope 2.0 program (8). From the ROC curve analysis, paired estimates of sensitivity and specificity of ELISA in relation to MAT at various OD cut-off values were determined. To for each cut-off threshold established, the $\chi 2$ (chi-square) was calculated (31). The OD value that resulted in the highest sum of the sensitivity and specificity estimates was established as the cut-off point (36). The confidence interval (CI) was based on $95 \%$ of probability. The test accuracy was also calculated using the areas under the ROC curve. The correlation coefficient among the antibodies titres obtained for the positive samples by MAT and DO value found by ELISA was estimated by Pearson correlation coefficient. In that analysis the Statistical and Genetic Analyses System (SAEG) was used, according to Ribeiro Júnior (30).

\section{RESULTS}

\section{MAT}

Out of 282 bovine serum samples evaluated, $143(50.71 \%$, CI 95\%: $44.87 \%-56.55 \%$ ) were MAT positive. The farms located in the Nhecolândia sub-region presented the highest percentage of positive reactions $(71.80 \%$ for farm $4,65.12 \%$ for farm 3 and $50 \%$ for farm 2), followed by the farm located in the Paraguay sub-region (41.33\%) and by the farm located in Aquidauana (12.50\%). The serovar Hardjo (Hardjoprajitno) stood out with the highest frequency of positive reaction ( 84 samples $-58.74 \%$ of the positive samples), followed by Wolffi (47.55\%), Hardjo (Hardjobovis) (40.97\%) and Ballum (33.33\%). Almost all samples that reacted with the serovar Sejroe (13.99\% of the positive samples) as well as all the samples that reacted with Tarassovi (6.99\%) were from cattle on farms 3 and 4 in the Nhecolândia sub-region. The remaining serovars reacted with a smaller number of samples (Grippotyphosa - eight reactive samples, Bratislava - five samples, Shermani - four samples, Australis three samples, Pomona - two samples and Copenhageni - one sample) (Table 2). In relation to antibody titres it is possible to observe in Table 2 that for all herds and farms sampled the serovar Hardjo (Hardjoprajitno) stood out with the highest titres. In Nhecolândia sub-region, the serovar Hebdomadis revealed the highest levels in farm 4.

\section{IgG ELISA rLipL32}

Out of 282 bovine serum samples, 161 (57.09\%, CI 95\%: $51.31 \%-62.87 \%$ ) were positive using IgG ELISA rLipL32. The optical density (OD) 0.151 represented the optimum cutoff for the ELISA test and the highest sensitivity $(99.30 \%$, CI 95\%: $97.93 \%-100.0 \%)$ and specificity values $(86.33 \%$, CI $95 \%$ : $80.62 \%$ 


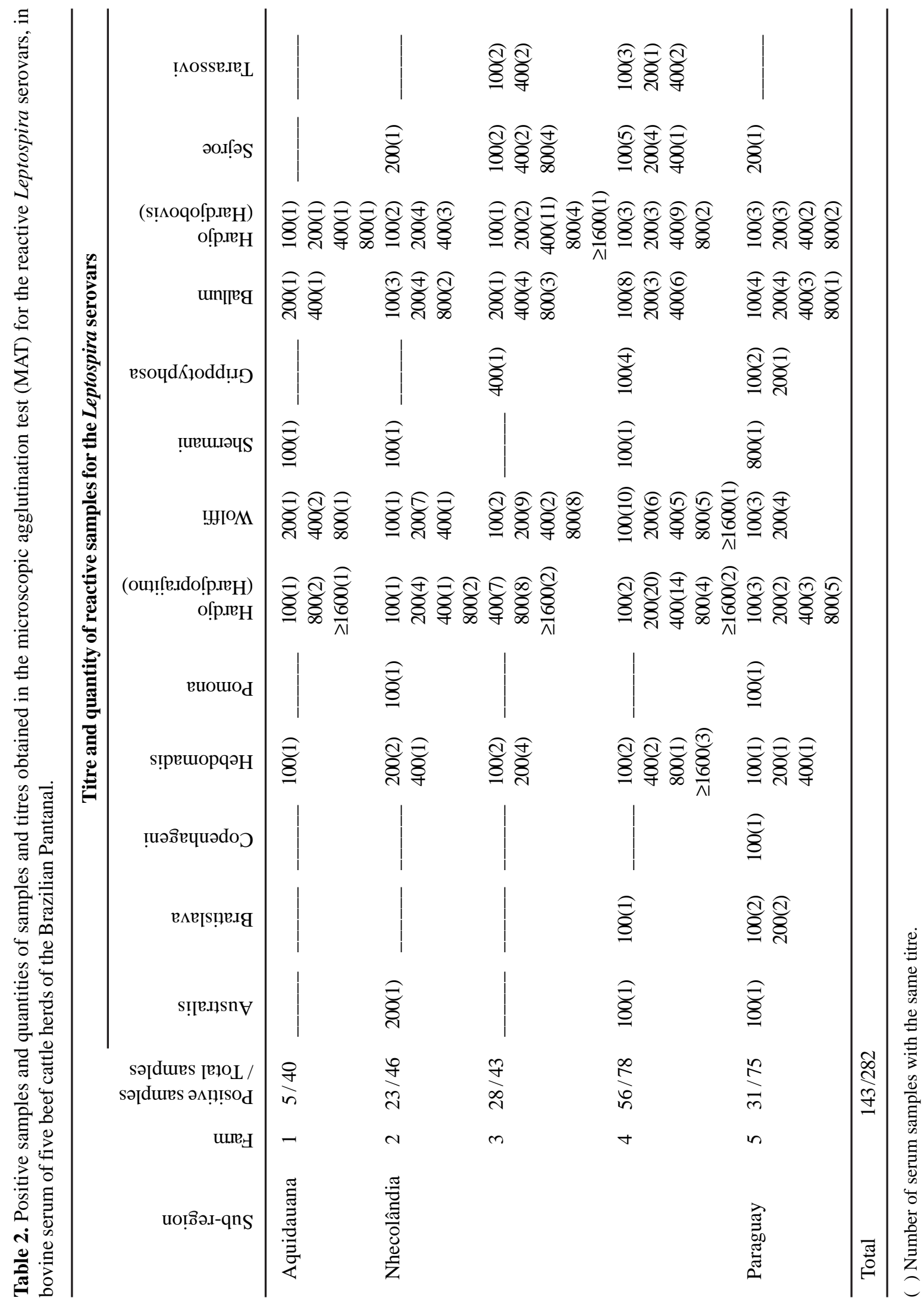


$-92.04 \%$ ) were obtained for this OD. The positive and negative predictive values for this cut-off were $88.20 \%$ (CI 95\%: $83.22 \%$ - 93.18\%) and 99.17\% (CI 95\%: 97.56\% - 100.0\%), respectively. The percentage of positive results obtained by ELISA was significantly higher $(\mathrm{p}<0.001)$ than that obtained by MAT. The discriminatory power of both tests (global accuracy), given by the area under the ROC curve, was $94.74 \%$ (CI 95\%: 93.22\% 96.25\%). No correlation between the titres by MAT and the absorbance by ELISA were observed ( $p>0.05)$. Absorbance values smaller than the cutoff $(\mathrm{OD}=0.151)$ could be observed in only one positive sample in MAT with a titre of 100.

\section{DISCUSSION}

Many animals are hosts of Leptospira spp., each serovar having one or more different hosts, each with different adaptation levels. The prevalence of leptospirosis depends on: a host which is the disseminator of Leptospira, the environmental contamination with live leptospires, the survival of these bacteria in this environment and the contact of susceptible individuals with the agent $(2,19)$. For the serovars to be adapted and maintained by bovines, direct transmission is a very important factor and seems to be independent of the region and climatic conditions, although dependent on herd management conditions, with transmission between bovines favored by intensive cattle production $(12,22)$. The serovars considered accidental and which are maintained by bovines are influenced by conditions which favor the maintenance of Leptospira spp. in the environment including: high temperature, high humidity and near neutral $\mathrm{pH}$ values. Leptospirosis infection has a highly dynamic and complex epidemiology, involving many serotypes and susceptible hosts. The presence of predisposing environmental factors and management cattle conditions should be analyzed according to these regional parameters (12).

Due to the high ambient temperature and humidity, associated with the large diversity of wildlife animals, the Pantanal presents favorable conditions to the dissemination and maintenance of leptospirosis at endemic levels. The seropositivity of this bacteria in bovine herds studied in the present work can be considered high, estimated at $50.71 \%$ by MAT and $57.09 \%$ by ELISA. Farms located in Nhecolândia subregion presented a higher percentage (varying from $71.80 \%$ to $50.00 \%$ ) of positive sera for lesptospirosis and farms located in Aquidauana sub-region presented a smaller percentage $(12.50 \%)$. This fact suggests that intrinsic differences in each bovine herd, probably related to the management conditions. Studies undertaken in Brazil have shown this aspect has a significant impact on leptospirosis prevalence and also the serovar distribution (21).

The most common agglutinating antibodies were reactive with the serovars Hardjo (Hardjobovis and Hardjoprajitno),
Wolffi and Ballum. The pathogenic serovar Hardjo maintained by bovines have been considered the major serovar in bovine herds in many countries, and include cases related to clinical bovine leptospirosis associated with reproductive problems $(2,3,20,29,32)$. The genotype Hardjobovis is also associated with chronic renal infections in bovines and genotype Hardjoprajitno is most commonly associated with reproductive problems (12). Recent studies in Brazil show Hardjo (Hardjoprajitno and Hardjobovis) and Wolffi as the most reactive serovars in bovine herds $(4,14,19,22,27,37)$. Some animal species which have been cited as accidentally infected by serovar Hardjo are capybara, deer, bubaline, equine, ovine, swine and $\operatorname{man}(5,15,23,29)$.

In Brazil, Cordeiro et al. 9) found the house mouse (Mus musculus brevirostris) and the four-eyed opossum (Philander opossum) as maintenance hosts of the Ballum serovar. Other authors have cited the wood mouse (Apodemus sylvaticus) and common mouse (Mus domesticus) as maintainers of this serovar $(2,17)$. In this studded, according to reports from owners, the wild rat and the skunk are animals which are frequently seen in all sampled farms, and therefore could be associated to the high reactivity found for the Ballum serovar. This leptospira serovar has been related to spontaneous abortion in cows (accidental infection) in Brazil $(20,32)$.

The serovar Sejroe previously reported as one of the most prevalent in the region of this present study was found mostly in Nhecolândia (13.99\%). The animal species reported as the maintenance host of this serovar is the wood mouse (Apodemus sylvaticus). Another serovar which stood out in Nhecolândia sub-region was Tarassovi. The wild boar (feral form of Sus scrofa) is considered as the major host responsible for the maintenance of this serovar (3) and according to Ebani et al. (11) some authors reported the existence of serovar Sejroe in this same animal species. In the Pantanal, the wild boar is very prevalent, mainly in the Nhecolândia sub-region (24). Since the animals infected by accidental serovars, as it is the case of Sejroe and Tarassovi, do not remain carriers of these serovars, this infection tends to limit itself to a single herd (29), explaining the existence of these serovars in specific herds.

The diagnosis of bovine leptospirosis using ELISA has been directed at the detection of the serovar specific antibodies using a variety of techniques to prepare antigens $(35,36,38)$.

Recombinant protein-based serologic tests present high sensitivity and specificity related to the high concentration of immunoreactive antigens which can be used in assays and the lack of nonspecific moieties present in whole-cell preparations (16). ELISA for leptospirosis has been used for human and animal infection diagnostic. Recombinant protein has been produced using porin transmembrane protein (OmpL1), lipoproteins (LipL32, LipL36 and LipL41) and a heat-shock protein (Hsp58), all of which have been used in ELISA for serodiagnosis of human leptospirosis (16). The LipL32 is a major leptospiral outer membrane protein whose expression is 
restricted to pathogenic Leptospira species and it is highly conserved within more than 250 pathogenic Leptospira serovars. LipL32 is also the major immunoreactive OMP shared by diverse serogroups (5). These characteristics suggest that LipL32 is useful for development of new leptospirosis serological diagnosis approaches (18).

In this study, IgG ELISA rLipL32 was used for diagnosis of bovine leptospirosis in comparison with standard test, MAT. The highest percentage of positive results was obtained by IgG ELISA rLipL32 (57.09\%) in comparison to MAT (50.71\%) $(\mathrm{p}<0.001)$. The IgG ELISA rLipL32 had a sensitivity of $99.30 \%$ and specificity of $86.33 \%$ relative to the MAT titres $\geq 100$ for different serovars that were tested. The sensitivity found in this study was lower than that reported by Bomfim et al. (7) $(100 \%)$ who evaluated the same recombinant antigen for the diagnosis of bovine leptospirosis, and was higher than that reported by Flannery et al. (16) (56\% and 94\% in the acute and convalescent phases, respectively) for diagnosis of human leptospirosis and by Dey et al. (10) (97\%) for diagnosis of canine leptospirosis. They reported a specificity of $100 \%, 95 \%$ and $97 \%$, for each cited authors respectively. The OD 0.151 found of the optimum cutoff for the ELISA rLipL32 in the present work was approximated of used in another studded of with bovine leptospirosis $(\mathrm{OD}=0,159)(7)$.

The high sensitivity and specificity of IgG ELISA rLipL32 obtained in this study corroborates the supposition of Flannery et al. (16): the conserved nature and high level of expression of protein LipL32 among pathogenic Leptospira spp. suggest that the IgG ELISA rLipL32 may exhibit similar performance regardless of the locally predominant serovar agent. Likewise, the high sensitivity and specificity associated to the high precision and accuracy of this test given by area under the ROC curve calculated in the present study $(94.74 \%)$, shows the potential of IgG ELISA rLipL32 to be widely applied for diagnosis of bovine leptospirosis. Advantages of the IgG ELISA rLipL32 in relation to MAT include: higher sensitivity, safety (since it eliminated the preparation of whole cell antigenic extracts of leptospirosis), an increase of throughput with a higher number of samples analyzed per batch, and an objective interpretation of results $(7,29)$.

In conclusion, the results confirm that IgG ELISA rLipL32 is a sensitive, specific and accurate test for diagnosis of bovine leptospirosis compared to MAT. Additionally, the Leptospira interrogans seropositivity found in this livestock indicated that the leptospirosis infection may be endemic in the Pantanal region and serovars Hardjo (Hardjoprajitno and Hardjobovis), Wolffi, and Ballum were the most reactive.

\section{ACKNOWLEDGEMENTS}

The authors thank not only the farmers for their collaboration in this research, but also the technical team of
EMBRAPA Pantanal for sample collecting, and FAPEMIG (Fundação de Amparo à Pesquisa do Estado de Minas Gerais) and $\mathrm{CNPq}$ (Conselho Nacional de Desenvolvimento Científico e Tecnológico) for their financial support. Edel F. BarbosaStancioli and Renata G. P. Tomich received fellowship from CNPq.

\section{RESUMO}

\section{Sorodiagnóstico de leptospirose em bovinos do Pantanal brasileiro utilizando ELISA IgG com proteína recombinante LipL32 e soroaglutinação microscópica}

Este estudo foi realizado no Pantanal brasileiro: região que apresenta importante biodiversidade. As condições de clima, hidrologia e geomorfologia dessa região, bem como a existência de grande variedade de espécies animais silvestres, favorecem a manutenção da Leptospira no meio ambiente. O objetivo desse estudo foi avaliar o ELISA IgG com proteína recombinante LipL32 em comparação com a soroaglutinação microscópica (SAM) para o diagnóstico sorológico de Leptospira. Adicionalmente, contribuir para o conhecimento da distribuição da leptospirose bovina, uma das mais importantes zoonoses mundialmente distribuída. Foi avaliada a soropositividade para essa bactéria em rebanhos bovinos de corte da região do Pantanal, uma área onde o bovino constitui não apenas o recurso econômico mais importante, como também a principal atividade econômica compatível com a conservação dos recursos naturais da região. Das 282 amostras de soro bovino analisadas, $143(50,71 \%)$ foram positivas na SAM. O sorovar Hardjo (genótipos Hardjoprajitno e Hardjobovis), Wolffi e Ballum apresentaram frequiências altas de amostras reativas. No $\operatorname{IgG}$ ELISA rLipL32, 161 amostras $(57,09 \%)$ foram positivas, apresentando esse teste uma maior soropositividade em relação à SAM $(\mathrm{p}<0,001)$. A Sensibilidade do ELISA em comparação com a SAM foi de $99,30 \%$ e a especificidade de $86,33 \%$. O IgG ELISA rLipL32 mostrou ser um teste sensível, específico e de alta acurácia para o diagnóstico de leptospirose bovina.

Palavras-chave: Leptospirose bovina, IgG ELISA rLipL32, SAM

\section{REFERENCES}

1. Abreu, U.G.P.; Moraes, A.S.; Seidl, A.F.; (2001). Tecnologias apropriadas para o desenvolvimento sustentado da bovinocultura de corte no Pantanal, Doc.24. Embrapa Pantanal, Corumbá.

2. Alonso-Andicoberry, C.; García-Peña, F.J.; Ortega-Mora, L.M.; (2001a). Epidemiología, diagnóstico y control de la leptospirosis bovina (Revisión). Invest. Agr.: Prod. Sanid. Anim., 16, 205-225.

3. Alonso-Andicoberry, C.; García-Peña, F.J.; Pereira-Bueno, J.; Costas, E.; Ortega-Mora, L.M.; (2001b). Herd-level risk factors associated with Leptospira spp. seroprevalence in dairy and beef cattle in Spain. Prev. Vet. Med., 52, 109-117. 
4. Araújo, V.E.M.; Moreira E.C.; Navega L.A.B.; Silva J. A.; Contreras R.L. (2005). Freqüência de aglutininas anti-leptospira interrogans em soros sanguíneos de bovinos, em Minas Gerais, de 1980-a 2002. Arq. Bras. Méd. Vet. Zootec., 57, 430-435.

5. Bello, N.A.; Lord V.; Laserma R. (1984). Enfermedades Infecciosas que afectam el chigüiri (Hidrochaeris hidrochaeris) en Venezuela. Rev. Vet. Venez., 278, 32-44.

6. Biswas, D.; Roy, S.; Vijayachari, P.; Sugunan, A.P.; Nararajaseenivasan K.; Sehgal, S.C. (2005). Comparison of immunoreactive proteins of commonly circulating serogroups of Leptospira in Andaman Islands, India. Indian J. Med. Res., 121, 151-158.

7. Bomfim, M.R.Q.; Ko, A.; Koury, M.C.; (2005). Evaluation of the recombinant LipL32 in enzyme-linked immunosorbent assay for the serodiagnosis of bovine leptospirosis. Vet. Microbiol., 109, 89-94.

8. CLIVE (2000). Win Episcope 2. Available at: http:// www.vetschools.co.uk/ EpiVetNet/ROC_analysis_software.htm. Download 17 December 2003

9. Cordeiro, F.; Sulzer, C.R.; Ramos, A.A.; (1981). Leptospira interrogans in several wildlife species in southeast Brazil. Pesq. Vet. Bras., 1, 19-29

10. Dey, S.; Mohan, C.M.; Kumar, T.M.A.S.; Ramadass, P.; Nainar, A.M,; Nachimuthu, K.; (2004). Recombinant LipL32 antigen-based single serum dilution ELISA for detection of canine leptospirosis. Vet. Microbiol., 103, 99-106

11. Ebani, V.V.; Cerri, D.; Poli, A.; Andreani, E.; (2003). Prevalence of Leptospira and Brucella antibodies in wild boars (Sus scrofa) in Tuscany, Italy. J. Wildlife, Dis., 39, 718-722.

12. Ellis, W.A.; (1994). Leptospirosis as a cause of reproductive failure. Vet. Clin. North Am. Food Anim. Pract., 10, 463-478.

13. Faine, S.; (1982). Guideliness for the control of leptospirosis. World Health Organization offset publication, 67, Geneva.

14. Favero, A.C.M.; Pinheiro, S.R.; Vasconcellos, S.A.; Morais, Z.M.; Ferreira, F.; Ferreira, Neto J.S.; (2001). Leptospirose bovina: variantes sorológicas predominantes em colheitas efetuadas no período de 1984 a 1997 em rebanhos de 21 estados do Brasil. Arq. Inst. Biol., 68, 29-35.

15. Favero, A.C.M.; Pinheiro, S.R.; Vasconcellos, S.A.; Morais, Z.M.; Ferreira, F.; Ferreira, Neto J.S.; (2002). Sorovares de Leptospira predominantes em exames sorológicos de bubalinos, ovinos, caprinos, eqüinos, suínos e cães de diversos Estados brasileiros. Cienc Rural, $32,613-619$.

16. Flannery, B.; Costa, D.; Carvalho, F.P.; Guerreiro, H.; Matsunaga, J.; Silva, E.D.; Ferreira, A.G.P.; Riley, L.W.; Reis, M.G.; Haake, D.A.; Ko, A.I.; (2001). Evaluation of recombinant Leptospira antigenbased enzyme-linked immunosorbent assay for the serodiagnosis of leptospirosis. J. Clin. Microbiol., 39, 3303-3310.

17. Haake, D.A.; Matsunaga, J.; (2005). Leptospiral membrane proteins: variations on a theme? Indian J. Med. Res., 121, 143-145.

18. Haake, D.A.; Chao, G.; Zuerner, L.; Barnett, J.K.; Barnett, D.; Mazel, M.; Matsunaga, J.; Levett, P.N.; Bolin, C.A.; (2000). The leptospiral major outer membrane protein LipL32 is a lipoprotein expressed during mammalian infection. Infect. Immun., 68, 2276-2285.

19. Homem, V.S.F.; Heinemamn, M.B.; Moraes, Z.M.; Vasconcellos, S.A.; Ferreira, F.; Ferreira-Neto, J.S.; (2001). Estudo epidemiológico da leptospirose bovina e humana na Amazônia oriental brasileira. Rev. Soc. Bras. Med. Trop., 34, 173-180.

20. Langoni, H.; Souza, L.C.; Silva, A.V.; Luvizotto, M.C.R.; Paes, A.C.; Lucheis, S.B.; (1999). Incidence of leptospiral abortion in brasilian dairy cattle. Prev. Vet. Med., 40, 271-275
21. Lilenbaum, W.; Costa dos Santos, M.R.; (1996). Effect of management systems on the prevalence of bovine leptospirosis. Vet. Rec., 138, 570-571.

22. Lilenbaum, W.; Souza, G.N.; (2003). Factors associated with bovine leptospirosis in Rio de Janeiro, Brazil. Res. Vet. Sci., 75, 249-251

23. Mathias, L.A.; Girio, R.S.; Duarte, J.M.B.; (1999). Serosurvey for antibodies against Brucella abortus and Leptospira interrogans in Pampas Deer from Brazil. J. Wildlife Dis., 35,112-114

24. Mourão, G.M.; Coutinho, M.E.; Mauro, R.A.; Tomás, W.M.; Magnusson, W.; (2002). Levantamentos aéreos de espécies introduzidas no Pantanal: porcos ferais (porco monteiro), gado bovino e búfalos, Bol. 28. Embrapa-CPAP, Corumbá.

25. National Research Council (1996). Guide for the care and use of laboratory animals. National Academy Press, Washington, D.C.;

26. O'Keefe, J.S.; (2002). A brief review on the laboratory diagnosis of leptospirosis. N. Z. Vet. J., 50, 9-13.

27. Oliveira, A.A.; Mota, R.A.; Pereira, G.C.; Langoni, H.; Souza, M.I.; Navegantes, W.A.; AS, M.E.; (2001). Seroprevalence of bovine leptospirosis in Garanhuns municipal district, Pernanbuco State, Brazil. Onderstepoort J. Vet. Res., 68, 275-279.

28. Pellegrinv A.O.; Sereno, J.R.B.; Leite, R.C.; Figueiredo, H.C.P.; (1997). Doenças da reprodução em bovinos no Pantanal: ocorrência de animais soropositivos para os vírus da rinotraqueíte Infecciosa Bovina, Diarréia Bovina à vírus e Língua Azul, Comunicado Técnico 20. Embrapa Pantanal, Corumbá.

29. Radostits, O.M.; Gay, C.C.; Blood, D.C.; Hinchcliff, K.W.; (2002). Clínica Veterinária: um tratado de doenças dos bovinos, ovinos, suínos, caprinos e eqüinos. Guanabara Koogan, Rio de Janeiro.

30. Ribeiro Júnior, J.I.; (2001). Análises estatísticas no SAEG. UFV, Viçosa.

31. Sampaio, I.B.M.; (1998). Estatística Aplicada à Experimentação Animal. Fundação de Ensino e Pesquisa em Medicina Veterinária e Zootecnia, Belo Horizonte.

32. Santana, A.O.B.; Oba, E.; Langoni, H.; Uribe, L.F.V. (1997). Aglutininas anti-leptospíricas em fêmeas bovinas repetiroras de cio. Rev. Bras. Rep. An., 21, 169-172

33. Seidl, A.; (2006). Biodiversity Conservation and Cattle Ranchers in the Brazilian Pantanal. In: Incentive Measures for Conservation of Biodiversity and Sustainability: Case Study of the Brazilian Pantanal, UNEP. Available at: http://www.biodiv.org/doc/case-studies/inc/cs-incbr-pantanal-en.pdf. Accessed 5 June 2006.

34. Silva, J.S.V.; Abdon, M.M.; (1998). Delimitações do Pantanal brasileiro e suas sub-regiões. Pesq. Agropec. Bras., 33, 1703-1711.

35. Surujballi, O.P.; Mallory, M.; (2001). Competitive enzyme-linked immunosorbent assay for detection of Leptospira interrogans serovar pomona antibodies in bovine sera. Clin. Diagn. Lab. Immun., 8, 40-43.

36. Surujballi, O.P.; Mallory, M.; (2004). An indirect enzyme-linked immunosorbent assay for the detection of bovine anti-bodies to multiple Leptospira serovars. Can. J. Vet. Res., 68, 1-6.

37. Viegas, S.A.R.A.; Caldas, E.M.; Oliveira, E.M.D.; (2001). Aglutininas anti-leptospira em hemosoro de animais domésticos de diferentes espécies, no Estado da Bahia, 1997/1999. Rev. Bras. Saúde Prod. An., 1, 1-6.

38. Yan, K.T.; Ellis, W.A.; Mackie, D.P.; Taylor, M.J.; Mcdowell, S.W.J.; Montgomery, J.M.; (1999). Development of an ELISA to detect antibodies to a protective lipopolysaccharide fraction of Leptospira borgpetersenii serovar hardjo in cattle. Vet. Microbiol., 69, 173187. 